ACTA UNIVERSITATIS WRATISLAVIENSIS

No 3996

PRZEGLĄD PRAWA I ADMINISTRACJI CXXIII

WROCŁAW 2020

https://doi.org/10.19195/0137-1134.123.20

\author{
MARIUSZ WIECZOREK \\ ORCID: 000-0003-4727-0895 \\ Uniwersytet Technologiczno-Humanistyczny \\ im. Kazimierza Pułaskiego w Radomiu
}

\title{
KILKA UWAG O OBOWIĄZKU LOJALNOŚCI RADCY PRAWNEGO
}

\begin{abstract}
Abstrakt: Lojalność, rozumiana jako uczciwe i rzetelne zachowanie w stosunkach międzyludzkich, ma szczególne znaczenie w przypadku osób wykonujących zawody zaufania publicznego. Jednym $\mathrm{z}$ takich zawodów, o których w art. 17 ust. 1 stanowi Konstytucja RP, jest zawód radcy prawnego. $\mathrm{W}$ artykule, na podstawie wniosków z analizy przepisów ustawy o radcach prawnych i postanowień Kodeksu Etyki Radców Prawnych, wykazano, że obowiązek lojalności radcy prawnego nie ogranicza się do relacji z klientem. O tej powinności radcy prawnego można mówić już na etapie poprzedzającym nawiązanie stosunku prawnego, w ramach którego świadczy on pomoc prawną na rzecz klienta. W związku z tym zaprezentowano pogląd, że w szczególnych przypadkach przejawem lojalności radcy prawnego może być odmowa udzielenia pomocy. W takim przypadku radca prawny powinien wskazać innego radcę, który będzie w stanie zapewnić pomoc prawną w danej sprawie. Obowiązek lojalności radcy prawnego istnieje też w relacjach między radcami prawnymi. W artykule zajęto stanowisko mówiące, że wzajemna lojalność radców prawnych jest warunkiem niezbędnym do wykonywania zawodu radcy prawnego jako zawodu zaufania publicznego w konstytucyjnym znaczeniu tego pojęcia.
\end{abstract}

Słowa kluczowe: radca prawny, lojalność, zawód zaufania publicznego, etyka radcowska

Lojalny to „uczciwy i rzetelny w kontaktach międzyludzkich”1. W świetle językowej definicji tego terminu lojalny może być wyłącznie człowiek — osoba fizyczna - wobec innego człowieka. Lojalny jest zatem ten, kto jest niezdolny do oszustwa, nie działa podstępnie, nie wykorzystuje zaufania innych. Lojalność przejawia się więc w zachowaniu człowieka, które może przybrać postać działania lub zaniechania, a przy tym nie istnieje sama w sobie — bez innego człowieka. Lojalność, mająca wymiar społeczny, może zatem przejawić się wyłącznie w inte-

${ }^{1}$ https://sjp.pl/lojalny (dostęp: 18.08.2020). Inny sposób rozumienia lojalności, wedle której lojalny to „postępujący zgodnie z nakazami władz, praworządny, prawomyślny”, nie będzie rozważany w tym artykule. Ten sposób pojmowania lojalności oznacza raczej lojalizm, który w pewnych okolicznościach może wyradzać się w konformizm. 
rakcjach z innymi ludźmi. Prawdziwość osądu o tym, czy dany człowiek jest lojalny, może stwierdzić wyłącznie inna osoba na podstawie zdobytych doświadczeń wynikających z kontaktów z tą osobą. Również autodeklaracja o tym, że jest się lojalnym, może być zweryfikowana co do prawdziwości wyłącznie przez kogoś innego, przez tego, kto oceni zgodność twierdzeń określonej osoby o jej własnych przymiotach w postaci rzetelności, uczciwości z zachowaniem osoby głoszącej ich posiadanie.

Skoro lojalność w zaprezentowanym ujęciu sama w sobie jest pozbawiona racji bytu i wymaga innego podmiotu, wobec którego można ją wykazać, to można postawić tezę o współzależności między lojalnością a zaufaniem, będącym swoistym rewersem lojalności. Jeśli odbieramy kogoś jako lojalnego, to jesteśmy skłonni obdarzyć taką osobę zaufaniem, na przykład powierzyć jej poufne informacje, oddać w zarząd mienie czy prosić o pomoc bez obawy zawodu.

Zaufanie według P. Sztompki jest ,zakładem podejmowanym na temat niepewnych, przyszłych działań innych ludzi” ${ }^{2}$ Z kolei F. Fukuyama pisze, że „zaufanie to mechanizm oparty na założeniu, że innych członków danej społeczności cechuje uczciwe i kooperatywne zachowanie oparte na wyznawanych normach"”. Już te dwie definicje potwierdzają tezę o swoistym współistnieniu lojalności i zaufania, które uzasadnia ich łączne postrzeganie.

Nie ulega przy tym wątpliwości, że lojalność i zaufanie są wartościami społecznymi ${ }^{4}$, przyczyniają się do budowania trwałych relacji społecznych, tworząc ważną podstawę ludzkiej aktywności i będąc przy tym podwaliną trwałych więzi mikro- i makrospołecznych. Trudne, wręcz niemożliwe, jest wyobrażenie sobie codziennego funkcjonowania bez zaufania i jego fundamentu - lojalności. Ich brak przekreśla naturalną ludzką potrzebę bezpieczeństwa, przynależności oraz identyfikacji z mniejszą lub większą strukturą społeczną — od rodziny, przez środowisko pracy i rozmaite, a zwłaszcza samorządowe, wspólnoty. Nielojalność eliminuje zaufanie, a niedostatek zaufania staje się źródłem lęku i dyskomfortu w różnych wymiarach życia człowieka. Lojalność i zaufanie są zatem cechami człowieka, które istotnie wpływają na nawiązywanie relacji międzyludzkich zarówno niesformalizowanych, jak i przybierających postać stosunków prawnych.

Zaufanie i lojalność mają szczególne znaczenie w związku z wykonywaniem zawodu radcy prawnego, będącego zawodem zaufania publicznego w rozumieniu art. 17 Konstytucji $\mathrm{RP}^{5}$. W literaturze przedmiotu trafnie zauważono, że przedsta-

2 P. Sztompka, Zaufanie. Fundament społeczeństwa, Kraków 2007, s. 70.

3 F. Fukuyama, Zaufanie. Kapitał społeczny a droga do dobrobytu, przeł. A. i L. Śliwa, Warszawa-Wrocław 1997, s. 38.

${ }^{4}$ D. Miłaszewicz, Zaufanie jako wartość społeczna, „Studia Ekonomiczne. Zeszyty Naukowe UE w Katowicach" 259, 2016, s. 83 n.

5 Konstytucja Rzeczypospolitej Polskiej z dnia 2 kwietnia 1997 roku, Dz.U. Nr 78, poz. 483 ze zm. W literaturze odrzuca się przy tym stanowczo tezę Sądu Najwyższego zawartą w wyroku z dnia 29 maja 2001 roku (I CKN 1217/98, OSNC 2002, nr 1, poz. 13), zgodnie z którą o statusie 
wiciele zawodów zaufania publicznego, a więc i radcowie prawni, odpowiadają za najbardziej żywotne interesy ich klientów, którzy powierzają im z reguły newralgiczne informacje na własny temat ${ }^{6}$. Jednocześnie osoby poszukujące pomocy prawnej zdają się na radców prawnych co do wyboru sposobu ochrony własnych interesów, gdyż z reguły, nie dysponując odpowiednią, specjalistyczną wiedzą, nie są w stanie ocenić, jakie działania byłyby optymalne w kwestii zabezpieczenia ich interesów ${ }^{7}$. Ta asymetria wymaga stworzenia prawnych gwarancji umożliwiających wytworzenie przekonania, że radca prawny nie tylko dysponuje stosowną wiedzą i umiejętnościami pozwalającymi na profesjonalne świadczenie pomocy prawnej, ale ze względu na przymioty charakterologiczne daje rękojmię, że nie zawiedzie zaufania, którym został obdarzony.

Lojalność radcy prawnego i zaufanie doń powinny być zatem rozważane przede wszystkim w relacji klient ${ }^{8}-$ radca prawny. Ramy tak rozumianych pojęć wyznaczają przepisy prawa określające wykonywanie zawodu radcy prawnego oraz postanowienia Kodeksu Etyki Radcy Prawnego9.

W refleksji poświęconej obowiązkowi lojalności radcy prawnego nie można jednak pominąć analizy obowiązku lojalności między radcami prawnymi. Jak zauważono w doktrynie, warunkiem sine qua non funkcjonowania zawodu zaufania publicznego w ujęciu Konstytucji RP jest spoiwo moralne, deontologiczne i organizacyjne grupy zawodowej zorganizowanej na zasadach samorządu ${ }^{10}$. Istotnym czynnikiem moralnym spajającym radców prawnych jest, i powinna być, ich wzajemna lojalność. Jej brak prowadziłby do rozbicia środowiska radców prawnych, niwecząc konstytucyjną ideę wyposażania wyodrębnionych zawodów zaufania społecznego w samorząd zawodowy. Lojalność w obrębie radców prawnych (lojalność zawodowa) sprawia, że osoby wykonujące ten zawód mogą zostać obdarzone zaufaniem przez podmioty poszukujące pomocy prawnej. Zainteresowany uzyskaniem tej pomocy, widząc, że radca prawny jest nielojalny wobec swoich koleżanek i kolegów, nie będzie skłonny do uczynienia „zakładu”, że radca prawny będzie lojalny wobec niego w sprawie, w której poszukuje pomocy prawnej,

zawodu zaufania publicznego można mówić wyłącznie odnośnie do tych profesji, które zostały za takie uznane w ustawie expressis verbis, por. T. Pietrzykowski, Radca prawny jako zawód zaufania publicznego, [w:] Zawód radcy prawnego. Historia zawodu i zasady jego wykonywania, red. A. Bereza, Warszawa 2015, s. 267 n.

6 T. Pietrzykowski, op. cit., s. 268.

7 Ibidem.

${ }^{8}$ Należy przyjąć, że adresatem obowiązku lojalność radcy prawego może być — inaczej niż w języku potocznym — nie tylko osoba fizyczna, lecz każdy podmiot poszukujący pomocy prawej.

9 Uchwała nr 3/2014 Nadzwyczajnego Krajowego Zjazdu Radców Prawnych w sprawie Kodeksu Etyki Radcy Prawnego (dalej: KERP), http://bibliotekakirp.pl/items/browse?collection=23 (dostęp: 16.09.2020).

10 M. Kulesza, Pojęcie zawodu zaufania publicznego, [w:] Zawody zaufania publicznego a interes publiczny - korporacyjna reglamentacja versus wolność wykonywania zawodu, oprac. S. Legat, M. Lipińska, Warszawa 2002, s. 29. 
a w rezultacie może albo zwrócić się do innych osób uprawnionych do świadczenia pomocy prawnej, albo w ogóle z niej zrezygnować.

Zatem obowiązek lojalności spoczywający na radcy oznacza nakaz postępowania uczciwego i rzetelnego zarówno wobec klientów, potencjalnych klientów, jak i radców prawnych. Obowiązek ten wypełnia się, w zależności od okoliczności, przez działanie (czynienie) albo zaniechanie (nieczynienie) ${ }^{11}$.

W artykule zostaną podjęte niektóre aspekty obowiązku lojalności radcy prawnego. Przede wszystkim zostanie podjęta próba wykazania, że obowiązek ten spoczywa na radcy prawnym z mocy przepisów prawa oraz etyki radcowskiej i to już na na etapie poprzedzającym świadczenie pomocy prawnej, a zatem lojalności wobec potencjalnego klienta.

W obszarze analizy znajdą się niektóre kwestie lojalności radcy prawnego wobec członków samorządu.

Rozważania prowadzone są przy założeniu, że lojalność radców prawnych jest koniecznym elementem wykonywania tego zawodu jako zawodu zaufania publicznego.

\section{OBOWIĄZEK LOJALNOŚCI RADCY PRAWEGO WOBEC POTENCJALNEGO KLIENTA}

O obowiązku lojalności radcy prawnego wobec klienta można mówić na etapie podejmowania się przez radcę prowadzenia konkretnej sprawy oraz $\mathrm{w}$ toku czynności z tą sprawą związanych. Podstawą sformułowania hipotezy o obowiązku lojalności nie tylko wobec jego klienta, lecz także wobec osoby (pomiotu) poszukującej pomocy prawnej, a zatem na etapie poprzedzającym zawarcie umowy o świadczenie pomocy prawnej, jest przede wszystkim treść art. 22 ust. 1 ustawy o racach prawnych ${ }^{12}$.

W kontekście obowiązku lojalności wobec potencjalnego klienta należy rozważyć, czy któraś z „ważnych przyczyn” w ujęciu art. 22 ust. 1 u.r.p., będących negatywnymi przesłankami udzielenia przez radcę pomocy prawnej klientowi jej poszukującemu, w związku z obowiązkiem lojalności wobec ,potencjalnego klienta" może determinować konieczność odmowy udzielenia pomocy prawnej w kontekście obowiązku lojalności ${ }^{13}$.

11 Oczywiście radca prawny powinien być lojalny również życiu osobistym, w sferze prywatnej. Wynika to jednoznacznie z art. 24 ust. 1 pkt 5 u.r.p. Ten obszar pozostanie poza zakresem zainteresowania.

12 Ustawa z dnia 6 lipca o 1982 roku radcach prawnych, tekst jedn. Dz.U. z 2020 r. poz. 75 (dalej: u.r.p.).

13 Zakładam przy tym, że udzielenie pomocy prawnej mimo zaistnienia przesłanek określonych postanowieniami rozdziału 2 KERP będzie jednoznaczne z naruszeniem przez radcę prawego obowiązku lojalności. 
Dalsze wywody poświęcone zasygnalizowanemu problemowi badawczemu zacząć należy od tego, że „ważne przyczyny” $\mathrm{z}$ art. 22 ust. 1 u.r.p. są przy tym przykładem ustawowych zwrotów szacunkowych, będących postacią stosowanych przez prawodawcę w aktach normatywnych zwrotów niedookreślonych ${ }^{14}$. Ich rolą jest wyeliminowanie kazuistyki prawa przez wprowadzenie od obowiązujących aktów normatywnych zwrotów niedookreślonych znaczeniowo pozwalającym ich adresatom na ostateczne określenie reguły zachowania w konkretnej sprawie ${ }^{15}$. Tak rozumiane zwroty niedookreślone, do których należą ważne przyczyny, oznaczają wprost pewne fakty, których ustalenie in concreto może, co podkreśla się $\mathrm{w}$ doktrynie, nastręczać problemów ${ }^{16}$. Rozstrzygnięcie tych problemów, w świetle art. 22 ust. 1 u.r.p., spoczywać będzie na radcy prawnym, który ostatecznie zdecyduje, w granicach uznania wyznaczonego publicznoprawnym statusem zawodu radcy prawnego, w tym ciążącym na nim obowiązkiem lojalności oraz okolicznościami danej sprawy, czy może odmówić udzielenia pomocy prawnej.

W literaturze przedmiotu zaproponowano klasyfikację zdarzeń mieszących się w pojęciu ważnych przyczyn, o których stanowi art. 22 ust. 1 u.r.p. Wyodrębniono: 1. zjawiska zewnętrzne (wypadki losowe, awaria sprzętu, przyczyny dotyczące wyposażonych w odrębną podmiotowość jednostek organizacyjnych, w których radca wykonuje swój zawód); 2. zdarzenia odnoszące się do klienta (domaganie się pomocy, która byłaby czynem bezprawnym lub godzącym w zasady etyki zawodowej); 3. zdarzenia dotyczące osoby radcy prawnego — choroba, urlop, kolizja interesów, brak zaufania do klienta ${ }^{17}$. Wskazuje się też, że część „ważnych przyczyn” została unormowana zarówno przepisami u.r.p., jak i KERP, inne zaś nie mają wyraźnego odpowiednika w ustawie i jest wywodzona z ogólnych zasad wykonywania zawodu radcy prawnego ${ }^{18}$.

W tym kontekście szczególne miejsce znajduje jedna z przesłanek odmowy udzielenia pomoc prawnej, określona w art. 12 ust. 2 KERP. Stanowi on, że radca prawny nie może podjąć się prowadzenia sprawy, jeżeli nie ma wystarczającej wiedzy lub doświadczenia. Okoliczności te nie są przeszkodą w przyjęciu sprawy, jeśli radca zapewni sobie współpracę mającego stosowną wiedzę lub doświadczenie radcy prawnego lub adwokata albo osoby, z którą radca na może na podstawie przepisów prawa wykonywać zawód ${ }^{19}$.

${ }_{14}$ M. Śliwka, Znaczenie zwrotów niedookreślonych na tle orzecznictwa polskiego Trybunatu Konstytucyjnego, „Stidia Iuririca Lublinensia” 2010, nr 13, s. 262.

15 Por. L. Leszczyński, Tworzenie generalnych klauzul odsyłajacych, Lublin 2001, s. 15.

16 System Prawa Prywatnego, t. 1. Prawo cywilne - część ogólna, red. Z. Radwański, M. Zieliński, M. Safjan, Warszawa 2012, s. 391.

17 B. Soltys, [w:] Ustawa o radcach prawnych. Komentarz, red. T. Scheffler, Warszawa 2018, s. 278.

18 Ibidem.

19 Postanowienie KERP w sposób oczywisty nawiązuje do treści art. 1.3 Kodeksu Etyki Prawników Europejskich — prawnik nie podejmuje się prowadzenia sprawy, jeśli wie lub powinien wiedzieć, że nie ma dostatecznych kompetencji do jej prowadzenia bez współpracy z prawnikiem, 
Nie ulega wątpliwości, że odmowa udzielenia pomocy w związku z art. 12 ust. 2 KERP wymaga szczególnej ostrożności ze strony radcy prawnego. Zacząć należy od tego, że od radcy prawnego wymaga się szerokiego spektrum wiedzy i umiejętności z zakresu prawa ${ }^{20}$. Co do zasady zatem radca prawny powinien móc udzielić pomocy prawnej w sprawach, które mieszczą się w kanonie wiedzy prawniczej wymaganej od radców prawnych. Jednak nie można nie zauważyć, że dynamicznie zwiększający się przedmiotowy zakres regulacji prawnej, wielka niestabilność prawa oraz jakość legislacji tworzą poważne wyzwania zawodowe. Jednym z rezultatów tego stanu rzeczy jest zjawisko specjalizacji radców prawnych $\mathrm{w}$ sprawach określanych przepisami różnych gałęzi prawa. Ten fenomen znalazł zresztą swoje odzwierciedlenie w art. 31 ust. 1 pkt 1 KERP, przewidującym, że informacja o wykonywaniu zawodu może zawierać preferowane zakresy praktyki zawodowej. W moim przekonaniu informowanie o preferowanych obszarach praktyki zawodowej jest przejawem lojalności wobec potencjalnego klienta, który dzięki takiej wskazówce przynajmniej wstępnie będzie mógł dokonać rozeznania rynku usług prawniczych, pozwalającego mu na skorzystanie z pomocy wyspecjalizowanego prawnika. Jednocześnie informacja tego rodzaju powinna być traktowana jako wzmocnienie ciążącego na radcy prawnym z mocy z art. 22 ust. 1 u.r.p. obowiązku świadczenia pomocy prawnej. Gdyby radca prawny odmówił przyjęcia sprawy z zakresu, w którym uznaje się za specjalistę, czemu daje wyraz w stosownej informacji, to w moim przekonaniu byłby to co do zasady przypadek kwalifikujący się do pociągnięcia takiego radcy prawnego do odpowiedzialności dyscyplinarnej z powodu nieuprawnionej odmowy udzielenia pomocy prawnej.

Jednym $\mathrm{z}$ aspektów nieudzielenia pomocy prawnej w związku $\mathrm{z}$ art. 22 ust. 1 KERP jest, czy radca prawny w takiej sytuacji powinien poinformować o konkretnej przyczynie odmowy, czy też wystarczy, że ograniczy się do ogólnikowego stwierdzenia, że zaistniała doniosła prawnie okoliczność uniemożliwiająca mu udzielenie pomocy prawnej. W literaturze podkreśla się, że de lege lata radca prawny odmawiający udzielenia pomocy prawnej nie ma obowiązku wskazania przyczyny odmowy, wystarczy, że powoła się na istnienie takiej przyczyny ${ }^{21}$. Wydaje się jednak, że względy deontologii zawodowej wręcz nakazują jej przedstawienie osobie poszukującej pomocy prawnej22. Budowanie zaufania do wykonywanej przez radców profesji wymaga bowiem takiego traktowania potencjalnych

który posiada takie kompetencje. Prawnik nie przyjmuje zlecenia, jeśli nie jest w stanie wykonać go niezwłocznie z uwagi na inne obowiązki zawodowe.

${ }^{20}$ Przedmiotowe ramy wiedzy i umiejętności z zakresu prawa wymaganego od radcy prawnego wyznaczają przepisy określające zakres egzaminu wstępnego (art. $33^{1}$ u.r.p.) oraz egzaminu radcowskiego (art. $36^{4}$ ust. 5-8a u.r.p.).

21 B. Sołtys, op. cit., s. 280.

22 Warto zauważyć, że zgodnie z art. 28 ust. 1 ustawy z dnia 26 maja 1982 roku o adwokaturze (tekst jedn. Dz.U. z 2019 r. poz. 1513 ze zm.) adwokat może odmówić udzielenia pomocy tylko z ważnych powodów, o których informuje zainteresowanego. 
klientów, które prowadzić będzie do budowania wśród nich przeświadczenia, że nieudzielenie pomocy przez konkretnego radcę spowodowane jest obiektywnymi, prawnie relewantnymi okolicznościami, mającymi swe źródło w przepisach u.r.p. lub w postanowieniach KERP.

Podsumowując ten wątek rozważań, należy stwierdzić, że obowiązek lojalności radcy prawnego na etapie przyjęcia sprawy do prowadzenia, a zatem lojalność wobec potencjalnego klienta, oznacza powinność podejmowania się przez radcę prowadzenia wyłącznie takich spraw (udzielania pomocy prawnej), w których sam, lub we współpracy z innym prawnikiem, będzie w stanie odpowiednio udzielić pomocy prawnej, w sposób wyznaczony treścią u.r.p. i zasadami etyki zawodowej. Nie ulega przy tym wątpliwości, że zasadą jest obowiązek udzielenia przez radcę prawnego pomocy prawnej, a jej odmowa jest wyjątkiem.

\section{OBOWIĄZEK LOJALNOŚCI RADCY PRAWNEGO WOBEC INNYCH RADCÓW PRAWNYCH}

W KERP, odmiennie niż w u.r.p., został przewidziany obowiązek radcy prawnego do lojalności wobec członków samorządu radców prawnych. Stanowiący o nim expressis verbis art. 50 ust. 1 KERP umieszczony został w rozdziale IV KERP zatytułowanym „Stosunki między radcami prawnymi”23. Dalsze postanowienia zawarte $\mathrm{w}$ dziale IV KERP pozwalają określić, jakie zachowania radców prawnych w stosunkach między nimi uznaje się za lojalne. Wnioski płynące $\mathrm{z}$ analizy postanowień KERP ustalających reguły właściwego zachowania radców prawnych pozwalają na wyodrębnienie dwóch zasadniczych płaszczyzn, na których może dochodzić do naruszenia obowiązku lojalności zawodowej. Pierwszą z nich wyznaczają zachowania radcy prawego podejmowane niezależnie od tego, czy wiążą się z wykonywaniem czynności zawodowych w konkretnej sprawie (na przykład art. 50 ust. 3, art. 57 KERP). Do drugiej grupy nielojalnych wobec innych radców prawnych zachowań należy zaliczyć zachodzące w trakcie świadczenia pomocy prawnej, względnie na etapie bezpośrednio poprzedzającym jej udzielenie (na przykład art. 51, 53 KERP).

${ }^{23}$ Ubocznie każe to postawić pytanie, czy obowiązek lojalności ogranicza się do radców prawnych, czy obejmuje też aplikantów radcowskich, którzy z mocy art. 40 ust. 2 są częścią samorządu zawodowego. Warto przy tym zauważyć, że postanowienia działu czwartego KERP, poza art. 50 ust. 1, stanowią wyłącznie o relacjach między radcami prawnymi. Osobiście stoję na stanowisku, że zasady określające stosunki między radcami stosuje się (co do zasady) do aplikantów radcowskich odpowiednio. Odpowiednie stosowanie znajduje uzasadnienie w specyficznym statusie aplikantów radcowskich. Wprost do nich będzie jednak miał zastosowanie art. 52 ust. 1 KERP, zgodnie z którym radca prawny może zwrócić uwagę członkowi samorządu radcowskiemu postępującemu niezgodnie z zasadami etyki zawodowej. 
Zasadne wydaje się założenie, że naruszenia obowiązku lojalności radcy prawnego kwalifikujące się do zaliczenia ich do pierwszej z wymienionych grup ukierunkowane są - bezpośrednio lub pośrednio - na pozyskiwanie klientów. Jako szczególnie nielojalne wobec innych radców wykonujących zawód należy uznać działania zabronione w świetle art. 50 ust. 2-3 KERP. W kontekście zakazów wynikających z tych postanowień można zastanowić się, czy zakaz podejmowania czynności zmierzających do pozbawienia innego radcy prawnego zatrudnienia lub utraty klienta nie przeszkadza w zawarciu jednej z umów o zakazie konkurencji, o których stanowi art. $101^{1} \mathrm{i}$ n. kodeksu pracy ${ }^{24}$. W wyniku ich zawarcia radca prawny traciłby, w zakresie ustalonym umową, możliwość prowadzenia działalności konkurencyjnej wobec pracodawcy, świadczenia pracy w ramach stosunku pracy lub na innej podstawie w trakcie trwania stosunku pracy (art. $101^{1}$ k.p.) lub po ustaniu stosunku pracy (art. $101^{2}$ k.p.). Zasygnalizowany problem powstawałby oczywiście w sytuacji, w której związany zakazem konkurencji radca prawny wykonuje (wykonywał) zawód w ramach stosunku pracy, świadcząc pracę rzecz pracodawcy - radcy prawnego prowadzącego kancelarię ${ }^{25}$. Zważywszy na brzmienie art. 50 ust. 2-3 KERP oraz status prawny radcy prawnego, należy przyjąć, że istnieją — jeśli w ogóle — niezwykle ograniczone możliwości stosowania tego rodzaju praktyk. Umowa o zakazie konkurencji w ujęciu prawa pracy ma na celu zabezpieczenie interesu pracodawcy, którym jest niezmniejszenie poziomu zamówień (udziału w rynku) przez pracownika, który mógłby „przechwytywać” potencjalnych klientów pracodawcy, dzięki uzyskanej w okresie zatrudnienia wiedzy i kontaktom. Nie ulega zatem wątpliwości zasadność obowiązywania stosownych przepisów, z których strony stosunku pracy mogą czynić użytek. Należy jednak mieć na uwadze to, że gdy pracownikiem jest radca prawny, to ze względu na ograniczenia wynikające $\mathrm{z}$ art. 50 ust. 2-3 KERP nie będzie mógł podejmować działań polegających na przejmowaniu klientów swojego aktualnego lub byłego pracodawcy ${ }^{26}$.

Zastosowane kryterium analizy przejawów naruszenia obowiązku lojalności zawodowej nie prowadzi do wyodrębnienia dwóch zbiorów w pełni rozłącznych. Zabronione w świetle regulacji zawartych w dziale IV KERP działania radców prawnych, których celem jest pozyskanie klienta, podejmowane na etapie świadczenia pomocy prawnej jednocześnie $\mathrm{z}$ innym radcą prawnym i w związku ze świadczoną pomocą prawną należy zatem uznać za kwalifikowaną postać naruszenia zasad etyki zawodowej.

${ }^{24}$ Ustawa z dnia 26 czerwca 1974 roku — Kodeks pracy, tekst jedn. Dz.U. z 2019 r. poz. 1040 ze zm.

${ }^{25}$ Szczególnym wariantem tego stanu rzeczy byłaby sytuacja, w której radca prawny podejmuje działania, by ograniczyć możliwości wykonywania zawodu przez innego radcę prawnego, przez zawarcie z nim umowy o zakazie konkurencji.

${ }^{26}$ Uważam, że „współpraca” w art. 50 ust. 2 obejmuje nie tylko status wspólnika jednej ze spółek, w których radca może wykonywać zawód, ale również zatrudnienie pracownicze oraz cywilnoprawne. 
W wymiarze temporalnym obowiązek lojalności wobec członków samorządu trwa przez cały okres przynależności do korporacji i nie ustaje w trakcie zawieszenia prawa do wykonywania zawodu ${ }^{27}$.

\section{PODSUMOWANIE}

Ustawa o radcach prawnych nie stanowi expressis verbis o obowiązku lojalności radcy prawnego ani wobec klienta, ani wobec innych radców prawnych. Źródłem tej powinności są postanowienia KERP, które pozwalają też na jego dookreślenie $\mathrm{w}$ zależności od tego, czy adresatem tego obowiązku jest inny radca prawny, czy klient. Doniosłość omawianego obowiązku podkreślają wnioski z zastosowania argumentu a rubrica. O uczciwym i rzetelnym wykonywaniu czynności zawodowych oraz lojalności radcy prawnego świadczącego pomoc prawną stanowią odpowiednio art. 6 i 8 KERP, zawarte w dziale II, zatytułowanym „Podstawowe zasady zawodu oraz wartości i obowiązki etyczne radcy prawnego”.

Należy też przyjąć, że można mówić o wynikającym z art. 22 ust. $1 \mathrm{i}$ art. 12. ust. 2 KERP obowiązku lojalności radcy prawnego wobec potencjalnego klienta. Niedopuszczalność świadczenia pomocy prawnej z powodu zaistnienia określonych $w$ art. 12 ust. 2 KERP okoliczności trzeba uznać za egzemplifikację ustawowo niedookreślonego zwrotu $\mathrm{z}$ art. 22 ust. 1 u.r.p.

Obowiązek lojalności radcy prawnego pozostaje w ścisłym związku z zasadami etycznymi zawodu radcy prawnego, a zwłaszcza z zasadą szczególnego zaufania między klientem a radcą prawnym, zasadą służebnej roli radcy prawnego wobec klienta, zasadą koleżeństwa czy zasadą godności zawodu. Jak się wydaje, naruszenie niemal każdej z zasad etycznych, na których oparty jest KERP28, wiązać się będzie ze złamaniem obowiązku lojalności radcy prawnego - czy to wobec klienta (potencjalnego), czy wobec innych członków wspólnot samorządowej. Jednocześnie nielojalne w rozumieniu przepisów u.r.p. i postanowień KERP zachowania radcy prawnego, bez względu na to, czy ich ofiarą jest klient, czy inny radca prawny, stają w opozycji wobec zamiaru ustrojodawcy utworzenia zawodów zaufania publicznego.

W świetle przedstawionych wywodów zasadne staje się stwierdzenie, że wypełnianie przez radcę prawnego obowiązku lojalności jest warunkiem sine qua non funkcjonowania zawodu radcy prawnego jako zawodu zaufania publicznego w znaczeniu wynikającym z treści art. 17 ust. 1 Konstytucji RP.

27 Wyrok SN z dnia 8 grudnia 2005 roku, II CK 309/05, LEX 188551; wyrok SN z dnia 24 kwietnia 1997 roku, III SZ 1/97, OSNP 1998, nr 4, poz. 139.

28 Por. T. Scheffler, [w:] Kodeks Etyki Radcy Prawnego. Komentarz, red. T. Scheffler, Warszawa 2017, s. 11. 


\title{
SOME REMARKS ON THE DUTY OF LOYALTY OF AN ATTORNEY-AT-LAW
}

\begin{abstract}
Summary
Loyalty, construed as honest and reliable behaviour in interpersonal relations, is of particular importance in the case of persons practising professions of public trust. One of the professions mentioned in art. 17 (1) of the Constitution of the Republic of Poland is that of an attorney-at-law. In the present paper, based on the conclusions drawn from the analysis of the provisions of the Act on Attorneys-at-Law and the provisions of the Code of Ethics for Attorneys-at-Law, it has been shown that the duty of loyalty of attorneys-at-law is not limited to customer relations. One can speak about this obligation of an attorney-at-law already at the stage which precedes entering into a legal relationship under which the attorney provides legal assistance to the client. Therefore, it is proposed that, in specific cases, the loyalty of an attorney-at-law may result in a refusal to provide assistance to the client. When this happens, the attorney-at-law should indicate another attorney-at-law who will be able to provide legal assistance to the client in a given case. Furthermore, the duty of loyalty of an attorney-at-law also exists in relations between attorneys-at-law. The paper takes a position which assumes that the mutual loyalty of attorneys-at-law is a necessary condition for practising their profession as a profession of public trust in the constitutional sense of the term.
\end{abstract}

Keywords: attorney-at-law, loyalty, profession of public trust, ethics of an attorney-at-law

\section{BIBLIOGRAFIA}

Fukuyama F., Zaufanie. Kapitat społeczny a droga do dobrobytu, przeł. A. i L. Śliwa, Warszawa-Wrocław 1997.

Kodeks Etyki Radcy Prawnego. Komentarz, red. T. Scheffler, Warszawa 2017.

Kulesza M., Pojęcie zawodu zaufania publicznego, [w:] Zawody zaufania publicznego a interes publiczny - korporacyjna reglamentacja versus wolność wykonywania zawodu, oprac. S. Legat, M. Lipińska, Warszawa 2002.

Leszczyński L., Tworzenie generalnych klauzul odsyłajacych, Lublin 2001.

Miłaszewicz D., Zaufanie jako wartość społeczna, „Studia Ekonomiczne. Zeszyty Naukowe UE w Katowicach" 259, 2016.

Pietrzykowski T., Radca prawny jako zawód zaufania publicznego, [w:] Zawód radcy prawnego. Historia zawodu i zasady jego wykonywania, red. A. Bereza, Warszawa 2015.

Radwański Z., Zieliński M., [w:] System Prawa Prywatnego, t. 1. Prawo cywilne - czesść ogólna, red. M. Safjan, Warszawa 2012.

Sołtys B., [w:] Ustawa o radcach prawnych. Komentarz, red. T. Scheffler, Warszawa 2018.

Sztompka P., Zaufanie. Fundament społeczeństwa, Kraków 2007.

Śliwka M., Znaczenie zwrotów niedookreślonych na tle orzecznictwa polskiego Trybunału Konstytucyjnego, „Stidia Iuririca Lublinensia” 2010, nr 13.

\section{AKTY PRAWNE}

Konstytucja Rzeczypospolitej Polskiej z dnia 2 kwietnia 1997 roku, Dz.U. Nr 78, poz. 483 ze zm. Ustawa z dnia 26 czerwca 1974 roku — Kodeks pracy, tekst jedn. Dz.U. z 2019 r. 1040 ze zm. Ustawa z dnia 26 maja 1982 roku o adwokaturze, tekst jedn. Dz.U. z 2019 r. poz. 1513 ze zm. Ustawa z dnia 6 lipca 1982 roku o radcach prawnych, tekst jedn. Dz.U. z 2020 r. poz. 75. 


\section{ORZECZNICTWO}

Wyrok SN z dnia 24 kwietnia 1997 roku, III SZ 1/97, OSNP 1998, nr 4, poz. 139. Wyrok z dnia 29 maja 2001 roku, I CKN 1217/98, OSNC 2002, nr 1, poz. 13. Wyrok SN z dnia 8 grudnia 2005 roku, II CK 309/05, LEX 188551. 